\title{
Polygons Teaching Through Creative Drama in Mathematics Teaching
}

\author{
Esen ERSOY* \\ Ondokuz Mayıs University, Faculty of Education, Samsun, Turkey \\ *Corresponding author: www.esene@omu.edu.tr
}

Received May 13, 2014; Revised May 23, 2014; Accepted June 04, 2014

\begin{abstract}
Creative drama, one of the contemporary teaching methods, allows student to explore. Geometry teaching through creative drama, a teaching method, is the main focus of this study. In the study, creative drama practices were carried out aiming at two acquisitions pertaining to geometry learning area polygon learning area in 7th grade mathematics subject. In the study, the purpose is to put forward the applicability of creative drama in mathematics teaching. The study is a private case work and, workshop plan and an assessment form composed of 3 open-ended questions, which were developed by the researcher, were used as data collection tools. Descriptive analysis method was used in the analysis of the data. The practices were carried out with 40 students attending Samsun Gazi Primary School in the second term of 2012-2013 academic year. Within the scope of the practices, 20 students treated the subject via creative drama practices, while the other 20 students treated the subject via conventional method. In consequence of the application, it became apparent that the students in the creative drama group could better understand the processes of forming polygon, deriving polygon, forming a polygon similar to a polygon than the conventional group. As a result, it was concluded that it is positive for the acquisitions pertaining to polygon sub learning area to be provided via creative drama.
\end{abstract}

Keywords: creative drama, geometry teaching, mathematics education, mathematics teaching

Cite This Article: Esen ERSOY, "Polygons Teaching Through Creative Drama in Mathematics Teaching." American Journal of Educational Research, vol. 2, no. 6 (2014): 372-377. doi: 10.12691/education-2-6-7.

\section{Introduction}

Students's mathematics achievement is very important to teaching and learning of mathematics. Therefore, we need to increase the success in teaching using modern methods. There are a lot of very important nowadays. Creative drama in education which is an important teaching method is student-centered.

Creative drama is a teaching method which can be used in many fields (Fulford et. al., 2001). Today, one of the methods of learning-teaching and practise that starts from the unity of human and that aims simultaneously to improve the needs to know (wisdom), to hear (conscience and aesthetics) and to act (motion), which are common abilities of human, is "drama in education” (Akar Vural and Sommers, 2011; p. 1). Creative drama offers many opportunity for children for example, thinking, cooperatively, comminication, awareness, self-confidence.

Due to the contemporary approaches in education, creative drama method has been used to enable the person to be active, to learn by realizing, makes him a productive and creative person and also it helps the person to improve healthy social communication skills (Kaf, 1999:2). Creative thinking method plays a prominent role in mathematics learning process. Because, students is at the learning center. Student centered instruction should be taken into consideration to provide conceptual understanding.
The fundamental objectives of the fields of drama and creative drama in education are to improve the fields of affective and psychomotor behaviours (Adigüzel, 2013; p. 53). The creative drama has been used in education to serve multiple dimension of it: the students "arts education, the students social and emotional development, the support of the teaching of other cognitive subjects like language, history, mathematics, etc" (Fleming et all., 2004). Creative drama has an important place in the education of students (Jindal-Sanpe et. al., 2011).The students learn from what they are doing in creative drama. They are so active with creative activities. Creative drama is supported learning in the creative classrooms. Because, students learn new information, abilities, attitudes, experiences. During the creative drama activities, information should be analyzed, evaluated and interpreted by them.

Educational studies of drama is gradually gaining wide currency as a teaching method in each step of formal training, mass education and during the lessons (San, 1991). During creative drama lessons, students show positive attitude and concern. Creative drama is an activity that is improved by games in the course of education and thanks to its this property, it is the vital part of education (Üstündağ, 1994; quoted by Üstündağ, 2009; p. 25). Its use as a method in educational programs in recent years attract attention (Üstündağ, 2009). Creative drama is state of actions, extemporisations and animations which the 
participants produce by relying on their own creative inventions, genuine thoughts and knowledge (San, 1998).

Creative drama offers children the chance to explore themselves through the lives of fictional "others" in a safe space that enables mistakes to be made and learned from (Jindal-Sanpe et. al., 2011). Creative drama provide collaborative learning and learning by discover. Therefore, mathematics and creative drama is learned through exploring.

Mathematics as an abstract lesson, it contains many abstract topics (Martin, 1997). To understand a mathematical definition, to make a hypothesis and to prove it, to visualize and to solve the problems are fundamental in mathematics teaching (Jones, Mooney and Harries, 2002). Students who solving problem is located on the basis of mathematics education.

Field of geometry learning has a significant place in the elementary mathematics curriculum. It is required that various practices be included in the educational plans in order to enhance the success in geometry teaching (Swafford and others, 1997). Geometric models and geometric samples have important roles in mathematics teaching (Sherard, 1981). To understand a mathematical definition, to make a hypothesis and to prove it, to visualize and to solve the problems are fundamental in mathematics teaching (Jones, Mooney and Harries, 2002).

Especially, the geometry became tough and stressful for students but creative drama should be treated as a game and training creative activities. Creative dramatic activities gain to responsibilities, self confidence and collaboration. It is necessary that students actively take part in the practices to be arranged in particular. Mathematics learning with creative drama is more enjoyable. Because, dramatization is important for students to gain confidence, experience, express oneself and self-improvement. The fundamental of mathematics is to find a solution to the problems by understanding mathematics. It is necessary that in the solution of educational process, various teaching methods be included in the process. Geometry teaching through creative drama, which is a teaching method, forms the basis of this study. In our paper we will focus on creative drama in mathematics education.

\section{Methods}

Case study was used in the research. Case study allows one to determine what an event, a fact or individual's certain feature is and to make deep analysis (Gay and Airasian, 2000). In this research, applicability of the method of creative drama in mathematics subject was examined in detail.

\subsection{Study Group}

The research was conducted with 40 students studying at 7th grade Gazi Primary School in the second term in Samsun in the academic year of 2012-2013. Within the scope of implementation, 20 students were taught the subject through creative drama practices, while the other 20 students completed the process via conventional method. Teacher has used the "Teacher Guide Book" in traditional method. But, researcher applied to creative drama plan in the creative drama group. Students in creative drama group were observed to be very excited. Because, they had never seen such a lesson previously.

\subsection{Data Collection Tools}

In the research, an evaluation form, which was arranged by the researcher and is made up of 3 open-ended questions, was used as data collection tool.

In the study, primarily interviews were carried out with the 7th grade mathematics teachers of primary school and the subjects which the students had difficulty in learning and understanding geometry were investigated. In consequence of the interviews carried out, it was determined that the students had difficulty in learning and understanding congruent figures and similarity figures.

At the end of the study, the students were asked openended questions and the answers provided were analyzed. The research carried out is aiming at the applicability of creative drama and teaching of "congruent figures" and "similarity figures" in geometry teaching.

Before the creative drama practices, the open-ended questions arranged by the researcher were submitted to 5 persons who are experts on their branches and their approval that the questions are appropriate for the aim of the research were obtained.

\subsection{Analysis of Data}

The method of descriptive analysis was employed in the analysis of the data. Descriptive analysis is an analysis that makes it possible for the research questions to be organized according to the themes they produce, which allows for the quotations conspicuously reflecting the views of the individuals interviewed or observed, and which enables the findings obtained to be interpreted (Yıldırım and Şimşek, 2003).

In the study, creative drama practices were carried out aiming at the acquisition pertaining to congruency and similarity sub-learning field of geometry-learning field in the elementary education of 7th grade mathematics subject. The acquisitions are provided below.

1. Match the identical figures given below and explain the reasons.

2. Determine which of the following are similar and give reasons

3. Which of the following given in the shaded area are similar to and same as each other? Give reasons.

At the end of the creative drama practices, an evaluation form of 3 open-ended questions were applied to all of the students. The qualitative data derived from the open-ended questions were encoded, and their percent and frequency values were obtained. Application of the workshop devoted to method of creative drama was conducted at four course hours.

\section{Findings}

The following are the assessments of the responses given by the students of creative drama and traditional groups to the three open-ended questions. During the assessments of the questions, the responses of creative drama group were first evaluated and then the responses of the students taking traditional education were assessed. The findings each question are given below respectively. 
Question 1. Match the identical figures given below and explain the reasons.

The answers given by the students of creative drama group to the formation of identical figures are included in the Table 1.

Table 1. The percentage-frequency distribution of the answers to identical figures formation by the students of creative drama

\begin{tabular}{|c|c|c|}
\hline $\begin{array}{c}\text { Answers to the identical } \\
\text { condition among figures }\end{array}$ & $\begin{array}{c}\text { Number of } \\
\text { students }\end{array}$ & $\begin{array}{c}\text { Percentage } \\
\text { distribution }\end{array}$ \\
\hline $\begin{array}{c}\text { Correct answers to identical } \\
\text { figures }\end{array}$ & 18 & $90 \%$ \\
\hline $\begin{array}{c}\text { Wrong answers to identical } \\
\text { figures }\end{array}$ & 2 & $10 \%$ \\
\hline Total number of students & 20 & $100 \%$ \\
\hline
\end{tabular}

Table 1; the students who attended the implementations of creative drama were found out to give correct answers (90\%) at the level of determining identical figures. The comments to the open-ended questions by the students who correctly answered the identical figures confirmed the result. The percentage and frequency distribution of the obtained results are provided in the following table.

Table 2. The opinions of the students in the creative drama group to the formation of identical figures

\begin{tabular}{|c|c|c|}
\hline $\begin{array}{c}\text { The assessment of the comments } \\
\text { on identical condition }\end{array}$ & $\begin{array}{c}\text { Number of } \\
\text { students }\end{array}$ & $\begin{array}{c}\text { Percentage } \\
\text { distribution }\end{array}$ \\
\hline $\begin{array}{c}\text { The identical are at the same time } \\
\text { similar }\end{array}$ & 18 & $90 \%$ \\
\hline $\begin{array}{c}\text { The identical are the same as each } \\
\text { other }\end{array}$ & 15 & $75 \%$ \\
\hline $\begin{array}{c}\text { The identical have the same } \\
\text { number of sides }\end{array}$ & 13 & $90 \%$ \\
\hline $\begin{array}{c}\text { The direction and form of the } \\
\text { identical are the same }\end{array}$ & 16 & $80 \%$ \\
\hline $\begin{array}{c}\text { The number of sides and corners of } \\
\text { identical are the same }\end{array}$ & which the & 8 . \\
\hline
\end{tabular}

Table 2 shows the extent to which the students are successful in determining identical figures. The students of creative drama group thought correctly and made logical comments while determining identical figures. That the students sorted the qualifications of identical figures and why they chose identical figures can be clearly understood from the percentages in the above table.

The table of the percentage-frequency distribution of the first answers given by the students handling the lesson through conventional method is given in the table below.

The Table 3 revealed that the students in the conventional method group had trouble determining the identical figures.

Table 3. The percentage-frequency distribution of the answers to identical figures formation by the students of conventional method

\begin{tabular}{|c|c|c|}
\hline $\begin{array}{c}\text { Answers to the identical } \\
\text { condition among figures }\end{array}$ & $\begin{array}{c}\text { Number of } \\
\text { students }\end{array}$ & $\begin{array}{c}\text { Percentage } \\
\text { distribution }\end{array}$ \\
\hline $\begin{array}{c}\text { Correct answers to identical } \\
\text { figures }\end{array}$ & 9 & $45 \%$ \\
\hline $\begin{array}{c}\text { Wrong answers to identical } \\
\text { figures }\end{array}$ & 11 & $55 \%$ \\
\hline Total number of students & 20 & $100 \%$ \\
\hline
\end{tabular}

This table have revealed to answers to identical figures formation of conventional group. The wrong answers given by the students in the process of determining identical figures ( $\mathrm{f}=11,55 \%$ ) revealed that they couldn't understand the subject well during the lesson. The comments on the open-ended questions given by the students who gave wrong answers to identical figures confirm the consequence. The percentage and frequency distribution of the obtained results are provided in the following table.
Table 4. The opinions of the students in the conventional method group to the formation of identical figures

\begin{tabular}{|c|c|c|}
\hline $\begin{array}{c}\text { The assessment of the comments } \\
\text { on identical condition }\end{array}$ & $\begin{array}{c}\text { Number of } \\
\text { students }\end{array}$ & $\begin{array}{c}\text { Percentage } \\
\text { distribution }\end{array}$ \\
\hline $\begin{array}{c}\text { The magnitude of the identical } \\
\text { figures are the same }\end{array}$ & 4 & $20 \%$ \\
\hline $\begin{array}{c}\text { The number of sides of identical } \\
\text { figures are the same }\end{array}$ & 4 & $20 \%$ \\
\hline $\begin{array}{c}\text { Those who couldn't comment on } \\
\text { identical condition }\end{array}$ & 12 & $60 \%$ \\
\hline
\end{tabular}

Table 4 revealed that the students in the conventional method group didn't know how they determined the identical figures. The answers given to the open-ended questions by the students who found the identical figures remained restricted to the only fact that the magnitude and the number of sides of identical figures are the same. In accordance with the obtained results, it is understood that the opinions couldn't be expressed (60\%) on how and according to what the determination of identical figures would be made.

Question 2. Determine which of the following are similar and give reasons.

The answers given by the students of creative drama group to the formation of similar figures are included in the Table 5.

Table 5. The percentage-frequency distribution of the answers to similar figures formation by the students of creative drama

\begin{tabular}{|c|c|c|}
\hline $\begin{array}{c}\text { Answers to the similar condition } \\
\text { among figures }\end{array}$ & $\begin{array}{c}\text { Number of } \\
\text { students }\end{array}$ & $\begin{array}{c}\text { Percentage } \\
\text { distribution }\end{array}$ \\
\hline $\begin{array}{c}\text { Correct answers to similar } \\
\text { figures }\end{array}$ & 13 & $\% 65$ \\
\hline $\begin{array}{c}\text { Wrong answers to similar } \\
\text { figures }\end{array}$ & 7 & $\% 35$ \\
\hline Total number of students & 20 & $\% 100$ \\
\hline
\end{tabular}

According above table, students knew the similar condition among figures in creative drama group.

Table 5; $65 \%$ of the students who participated in the creative drama implementations determined the similar figures but $35 \%$ of them found the similar figures in a wrong way. It was found out from the given answers that the students confused similar figures with the same figures. In the evaluations of the asked open-ended questions, it was concluded that they actually knew the features of similar figures but they had a confusion on the figures. Table 6 is of importance in terms of to what criteria the features of similar figure formation were determined.

Table 6. The opinions of the students in the creative drama group to the formation of similar figures

\begin{tabular}{|c|c|c|}
\hline $\begin{array}{c}\text { The assessment of the comments on } \\
\text { similar condition }\end{array}$ & $\begin{array}{c}\text { Number of } \\
\text { students }\end{array}$ & $\begin{array}{c}\text { Percentage } \\
\text { distribution }\end{array}$ \\
\hline Similar figures are not the same & 13 & $65 \%$ \\
\hline $\begin{array}{c}\text { The magnitudes of similar figures } \\
\text { are different from each other }\end{array}$ & 10 & $50 \%$ \\
\hline $\begin{array}{c}\text { The proportion of similar figures to } \\
\text { each other is 1 }\end{array}$ & 12 & $60 \%$ \\
\hline Similar figures are not the same & 13 & $65 \%$ \\
\hline $\begin{array}{c}\text { The magnitude of similar figures } \\
\text { are proportionate to each other }\end{array}$ & 12 & $60 \%$ \\
\hline
\end{tabular}

Table 6 revealed that the students who took part in the creative drama group implementations didn't have any difficulty determining similar figures and expressing their opinions. It is concluded that the students made comments by knowing similarity and the features of similar figures.

The expressions made to the open-ended questions by the students in the conventional group are given in the Table 7 . 
Table 7. The percentage-frequency distribution of the answers to similar figures formation by the students of conventional method

\begin{tabular}{|c|c|c|}
\hline $\begin{array}{c}\text { Answers to the similar condition } \\
\text { among figures }\end{array}$ & $\begin{array}{c}\text { Number of } \\
\text { students }\end{array}$ & $\begin{array}{c}\text { Percentage } \\
\text { distribution }\end{array}$ \\
\hline $\begin{array}{c}\text { Correct answers to similar } \\
\text { figures }\end{array}$ & 9 & $\% 45$ \\
\hline $\begin{array}{c}\text { Wrong answers to similar } \\
\text { figures }\end{array}$ & 11 & $\% 55$ \\
\hline Total number of students & 20 & $\% 100$ \\
\hline
\end{tabular}

According above table, conventional group failed to determine in similar condition among figures. The table above disclosed that the students having the lessons through conventional methods had difficulty determining similar figures. $45 \%$ of the students determined the similar figures correctly, while $55 \%$ of them determined them wrongly. This situation determined that conventional group failed to formation in similar figures.

The expressions made to the open-ended questions by the students in the conventional group are given in the table below.

Table 8. The opinions of the students in the conventional method group to the formation of similar figures

\begin{tabular}{|c|c|c|}
\hline $\begin{array}{c}\text { The assessment of the comments } \\
\text { on similar condition }\end{array}$ & $\begin{array}{c}\text { Number of } \\
\text { students }\end{array}$ & $\begin{array}{c}\text { Percentage } \\
\text { distribution }\end{array}$ \\
\hline $\begin{array}{c}\text { The dimensions of similar figures } \\
\text { are different from one another }\end{array}$ & 4 & $20 \%$ \\
\hline $\begin{array}{c}\text { Those who couldn't comment on } \\
\text { similarity condition }\end{array}$ & 16 & $80 \%$ \\
\hline
\end{tabular}

Considering the evaluations of open-ended questions, the students having determined (45\%) the similar figures seemed to be insufficient in their assessments of figure formation, while $20 \%$ of the students considered the similarity only as the differentiation in dimensions. The obtained result is insufficient in terms of similarity and revealing the features of similar figures. Because, $80 \%$ of the students didn't comment on similarity condition, this score is very high.

Question 3.- Of the figures given in the shaded area below, find the ones which are identical and the ones that are similar. And, explain why.

The answers given to the mentioned open-ended question was assessed in two stages as correct and wrong. What percent of the answers given by the students was determined to be correct or wrong. Table 9 states the answers given by the students in the process of determining the similar and same figures.

Table 9. The percentage table of identical and similar figures formation by the students of creative drama

\begin{tabular}{|c|c|c|}
\hline $\begin{array}{c}\text { Determining the } \\
\text { identical and } \\
\text { similar figures }\end{array}$ & $\begin{array}{c}\text { The number of } \\
\text { students who made } \\
\text { correct determination }\end{array}$ & $\begin{array}{c}\text { The number of } \\
\text { students who made } \\
\text { wrong determination }\end{array}$ \\
\hline $\begin{array}{c}\text { Determining } \\
\text { identical figures }\end{array}$ & $16(80 \%)$ & $4(20 \%)$ \\
\hline $\begin{array}{c}\text { Determining } \\
\text { similar figures }\end{array}$ & $19(95 \%)$ & $1(5 \%)$ \\
\hline
\end{tabular}

Table 9 revealed that the process of teaching with creative drama contributed to the process of determining identical and similar figures. $80 \%$ of the students determined the identical figures, while $95 \%$ of them determined similar figures correctly. From the answers given to the open-ended questions the reasons for determining identical and similar figures correctly or wrongly are given below.

In the correct determination of identical figures, students commented that the angles and dimensions of the figures are the same, and their number of edges are identical to each other and similar. In the correct determination of similar figures they interpreted that the dimensions of the figures are different, the similar ones are not the same and they are minimized versions of one another in certain amounts.

In the wrong determination of identical figures, 4 students (20\%) gave wrong answers. It was found out that these students confused identical figures to similar figures and they were mistaken in the positions of figures. From the positions of non-identical figures in different directions, they were inferred to give identical features. 1 students (5\%) couldn't interpret the similarity in the process of wrong determination of similar figures. 5\% percent of the students stated that the similarity vanished when the geometrical figure was turned. Some opinions were found out about the fact that the geometrical figure lost its similarity feature when it was turned from straight position to up-right position.

The obtained findings on the determination of similar and identical figures in the class where conventional teaching is implemented are given in the following table.

Table 10. The percentage table of identical and similar figures formation by the students of conventional method

\begin{tabular}{|c|c|c|}
\hline $\begin{array}{c}\text { Determining the } \\
\text { identical and } \\
\text { similar figures }\end{array}$ & $\begin{array}{c}\text { The number of } \\
\text { students who made } \\
\text { correct determination }\end{array}$ & $\begin{array}{c}\text { The number of } \\
\text { students who made } \\
\text { wrong determination }\end{array}$ \\
\hline $\begin{array}{c}\text { Determining } \\
\text { identical figures }\end{array}$ & $6(\% 30)$ & $14(\% 70)$ \\
\hline $\begin{array}{c}\text { Determining } \\
\text { similar figures }\end{array}$ & $11(\% 55)$ & $9(\% 45)$ \\
\hline
\end{tabular}

Table 10 revealed that the students in the conventional method group didn't know how they determined the identical figures. Also, Table 10 indicates that the students in the classes of conventional teaching had difficulty determining identical figures. $30 \%$ of the students determined the identical figures correctly, while $70 \%$ of them determined them wrongly. For similar figures the students were observed to display a little more positive attitude. In accordance with the answers given to the openended questions, correct-wrong evaluations emerged in determining identical and similar figures.

In the correct determination of identical figures the dimension of the figure was stated to be the same, while in the determination of similar figures the number of corners were stated to be the same. Considering the correct statements, the students were determined to be hesitant to write comments. In the evaluation of open-ended questions, the inadequacy of the comments attracted attention. This situation reveals that the students cannot express their opinions where they are passive but the teacher is active.

In the level of wrong determination of identical figures, the students were determined to understand that the dimension changed when the figure was turned. Answers that the identical figures which were turned up-right position were not identical were taken. There are students who stated that the sizes changed through the turning.

In the level of wrong determination of similar figures, $45 \%$ of the students were found to confuse the identical figures to similar figures. At this level, 9 students didn't know the features of identical and similar figures and how they could be interpreted when they were turned. This ratio is an amount to be taken into consideration in the education process. 


\section{Result and Conclusion}

Creative drama groups students who correctly answered the identical figures confirmed the result. The students of creative drama group thought correctly and made logical comments while determining identical figures. They actually knew the features of similar figures but they had a confusion on the figures. They made comments by knowing similarity and the features of similar figures and commented that the angles and dimensions of the figures are the same, and their number of edges are identical to each other and similar.

Dramatic activities will plan for dividing responsibilities, roles and opportunities in the performance, introducing and implementing the activity for the students, and facilitating student learning (Masoum et all., 2013). All roles have significant effect on students in mathematics lesson. Creative drama acticities are effective in gaining of these skills. Especially, students' participation is more useful in mathematics lesson. Dramatic activities can help to better learning of mathematical lesson. Therefore, this activities should be planned well. And, all activities should be used in accordance with the objective.

Creative drama is an effective method of students attains. In this study, creative drama group students are more successful than conventional group. Because, creative drama group students have taken an active role in the process. And, other group has taken an passive role in the process.

In the literature, there are a number of studies indicating similar results about the effectiveness of creative drama based instruction in the literature (Masoum et all., 2013, Debreli, 2011; Sengün and Iskenderoglu, 2010; Duatepe, 2004; Duatepe ve Ubuz, 2004; Ersoy, 2013; Jeong Wee, 2009; Kariuki \& Humphrey, 2006; Karakelle, 2009, Karapinarlı, 2007, Kayhan, 2004; Omnievski, 1999; Özsoy, 2003; Saab, 1987; Sözer, 2006).These studies showed the effectiveness of creative drama based instruction on understanding of mathematics lessons.

Saab (1987) examined the effects of drama-based mathematics instruction on sixth graders compared to textbook mathematics instruction and the results showed a significant increase in mathematics achievement. Duatepe and Ubuz (2004), gave place to development and practice of lesson plans aiming at using creative drama in teaching and learning of geometry subjects in teaching drama-based geometry. Breen and Hannula's work (2003) used playing and acting in a drama as an environment for mathematics educators reflection on different interpretations of mathematics classroom research findings. Masoum et all. (2013) study results show that game-based and dramatic practices can help to better learning of mathematical concepts and these students have better perception of concepts. Jeong Wee (2009), focused on the fact that the practices conducted with the experts in field of creative drama increased the sense of responsibility, that the student is at the center of learning and that the leader of drama is important. In the research carried out too, the author is expert on the field of creative drama. The workshop plan written by the author in the research was prepared and applied by the author. Thus, the workshops conducted by the person expert on his field allow the process to be completed ideally. According this study results, creative drama activities will be helpful to teach mathematical and geometric concepts.

Finally there are some suggestions for other reseaches; creative drama studies may prepare other topics in mathematics education; creative drama practice may extend to different class and schools; this study extended to academic achievement, mathematics attitude and mathematical thinking.

This study has indicated that creative drama method is efficient mathematics teaching. Especially, creative drama method is new method in geometry teaching. Consequently, this study is contributed to the field of study. It is believed that the findings of this study will give many effects for mathematics teaching and mathematics educator.

\section{References}

[1] Adıgüzel, Ö. (2013). Eğitimde Yaratıcı Drama. 3.Baskı. Pegem Yayıncılık. Ankara.

[2] Akar Vural, R. ve Somers, J.W. (2011). Hümanist İlköğretim Programları İçin İlköğretimde Drama: Kuram Ve Uygulama. Pegem Akademi. Ankara.

[3] Breen, C., Hannula, M.S. (2003). Exploring alternative interpretations of clasroom data. Proceedings of the 27th Conference of the International Group for the Psychology of Mathematics Education. Vol. Honolulu, USA, 174.

[4] Debreli, E. (2011). In Partial Fulfillment of the Requirements Fort the Degree of Master of Science in the Department of Elementary Science And Mathematics Education. A Thesis Submitted to the Graduate School of Social Sciences of Middle East Technical University. Ankara.

[5] Duatepe, A. and Ubuz, B. (2002). Drama based instruction and geometry. Retrieved july 01, 2005 from http//www.icmeorganisers.dk/tsg14.7TSG14-12.pdf.

[6] Duatepe, A. (2004). The Effects of Drama Based Instruction on Seventh Grade Students' Geometry Achievement, Van Hiele Geometric Thinking Levels, Attitude toward Mathematics and Geometry. Yayınlanmamış Doktora Tezi, Middle East Technical University, Ankara.

[7] Ersoy, E. (2013). Matematik Öğretiminde Yaratıcı Drama Kullanımı Üzerine Bir Uygulama. 12. Matematik Sempozyumu. Toplumda Matematik. Ankara.

[8] Fleming, M., Merell, C., Tymms, P. (2004). The impact of drama on pupils' language, mathematics and attitude in two primary schools. Research in drama education, 9 (2), 177-197.

[9] Fulford, J., Hutchings, M., Ross, A.\& Schimitz, H. (2001). İlköğretimde Drama. (Çev. Leyla Küçükahmet, Hande Borçbakan, S. Sadi Karamanoğlu). Ankara: Nobel Yayın Dağıtım.

[10] Gay, L.R. ve Airasian, P. (2000). Education Research. Competencies for Analysis and Application. Sixth Education.

[11] Jeong Wee, S. (2009). A Case Study Of Drama Education Curriculum For Young Childrenin Early Childhood Programs. Journal Of Research İn Childhood Education, 23: 4, 489-501.

[12] Jindal-Sanpe, D., Vettraino, E., Lowson, A. Ve Mcduff, W. (2011) Using Creative Drama To Facilitate Primary-Secondary Transition, Education 3-13: İnternational Journal Of Primary, Elementary And Early Years Education, 39:4, 383-394.

[13] Jones, K., Mooney, C. And Harries, T. (2002), Trainee Primary Teachers' Knowledge Of Geometry For Teaching, Proceedings Of The British Society For Research Into Learning Mathematics, 22 (2), 95-100.

[14] Kaf, Ö. (1999). The Effects Of Creative Drama Method On Developing Some Social Skills In 3rd

[15] Grade Social Studies Class Çukurova University. Social ScienceInstitute. Unpublished Master's thesis.

[16] Karakelle, S. (2009). Enhancing Fluent And Flexible Thinking Through The Creative Drama Process. Thinking Skills And Creativity 4. 124-129.

[17] Karapınarlı, R. (2007). İlköğretim 7. Sınıf Matematik Dersinde Yaratıcı Drama Yönteminin Öğrencilerin Başarı Ve Kalıcılık Düzeyine Etkisi. Muğla Üniversitesi Sosyal Bilimler Enstitüsü 
Eğitim Bilimleri-Eğitim Programları Ve Öğretimi Anabilim Dalı. Yüksek Lisans Tezi. Muğla.

[18] Kariuki, P.\& Humphrey, S.G. (2006, November). The Effects Of Drama OnThe Performance Of At Risk Elementary Math Students. Paper Presented At The Annual Conference Of The Mid-South Educational Research Association, Birmingham,Alabama.

[19] Kayhan, H.C. (2004). Yaratıcı Dramanın İlköğretim 3. Sınıf Matematik Dersinde Öğrenmeye, Bilgilerin Kalıcılı̆̆ına Ve Matematiği Yönelik Tutumlara Etkisi. Gazi Üniversitesi Eğitim Bilimleri Enstitüsü İlköğretim Bölümü Sınıf Öğretmenliği Bilim Dalı. Yüksek Lisans Tezi. Ankara.

[20] Masoum, E., Rostamy-Malkhalifeh, M., Kalantarnia, Z. (2013). A Study on the Role of Drama in Learning Mathematics. Mathematics Education Trends and Research. Volume 2013. Article ID metr-00016, 7 Pages.

[21] Martin, D.J. (1997). Elementary Science Methods. A Constructivist Approach. Delmar publishes, USA.

[22] Omniewski, R. (1999).The Effects Of An Artsİnfusion Approach On The Mathematics Achievement Of Second-Grade Students. Unpublished Doctoral Dissertation, The University Of Texas, USA.

[23] Özsoy, N. (2003). İlköğretim MatematikDerslerinde Yaratıcı Drama Yönteminin Kullanılması. BAÜ Fen Bilimleri Enstitüsü Dergisi, 5 (2), 112-119.

[24] Saab, J.F. (1987). The Effects of Creative Drama Methods on Mathematics Achievement, Attitudes And Creativity. Unpublished PhD Dissertion, West Virginia University, Morgantown.
[25] San, İ. (1998). Yaratıcı Drama Çalışmalarının Dünü Ve Bugünü. Ankara. 2. Ulusal Çocuk Kültürü Kongresi Bildirileri (Ed. Bekir Onur).

[26] Sengün, Y.,İskenderoğlu, T. (2010). A Review of Creative Drama Studies in Math Education: Aim, Data Collection, Data Analyses, Sample And Conclusion of Studies, Procedia Social And Behavioral Sciences, 9, 1214-1219.

[27] Sherard, W.H. (1981). Why is Geometry a Basic Skill? Mathematics Teacher. 74 (1), 19-21.

[28] Sözer, N. (2006). İlköğretim 4. Sınıf Matematik Dersinde Drama Yönteminin Öğrencilerin Başarılarına, Tutumlarına Ve Öğrenmenin Kalıcılığına Etkisi. Unpublished Master’s Thesis. Gazi Üniversitesi, Ankara.

[29] Swafford, J.O., Jones, G.A. Ve Thornton, C.A. (1997). Increased Knowledge İn Geometry And Instructional Practice. Journal For Research İn Mathematics Education. Vol. 28, No. 4, 467-483.

[30] Üstündağ, T. (2009). Yaratıcı Drama Öğretmenimin Günlüğü. Pegem Yayıncılık. 9. Baskı. Ankara.

[31] Wee, S.J. (2009). A Case Study of Drama Education in Early Childhood. Journal of Research in Childhood Education, 3 (4), 489-501.

[32] Yıldırım, A. ve Şimşek, H. (2003). Sosyal Bilimlerde Nitel Araştırma Yöntemleri. Seçkin Yayıncılık. Ankara. 